\title{
REVIEW \\ Josef Shatzmiller \\ Cultural Exchange: \\ Jews, Christians, and Art in the Medieval Marketplace
}

(Princeton and Oxford: Princeton University Press, 2013)

Merav Schnitzer, Tel Aviv University

"Moments of Grace" and "exciting results" were the words rightly chosen by Josef Shatzmiller to describe the main findings of his fascinating book, Cultural Exchange: Jews, Christians, and Art in the Medieval Marketplace (p. 160). Shatzmiller sought to uncover new avenues of cultural exchange between Jews and Christian in the high and late Middle Ages (ca. 1230 - 1450) in Germany, France, England, northern Italy, the Iberian Peninsula, and Sicily.

By studying the market of pawnbrokers, Shatzmiller discovered a deep encounter between Jews and Christians. It was a sphere in which Jews were willing to adopt the aesthetic values of Christian society, even when those were in contrast with halakha (Jewish law). Shatzmiller chose to rely in his study mainly on non-Jewish sources, rather than Jewish (halakhic) sources, as most of his predecessors did. Shatzmiller argues that for a deeper understanding of Jewish everyday life scholars must expand the scope of sources they use. In his study he uses a variety of sources, including archival texts (such as legal and administrative writings in Latin and vernacular languages) and material and artistic sources (such as illuminated manuscripts and ritual objects, both Jewish and Christian).

Shatzmiller describes a process of cultural assimilation in three main stages, with the market place as its first stage. The possession of Christian artifacts as pawns led Jews, as noted, to adopt the aesthetic values common in Christian society. In the 
highest point of this process, he shows that Jewish and Christian artists collaborated in both communities.

This process has been demonstrated in three parts of the book. The first part (chapters 1-3) focuses on the marketplace and the use of pawns and pledges. Numerous artifacts, including Christians' sacred objects, pieces of jewelry, and clothing were daily transferred from Christians to Jews. This created a daily encounter between Jews and Christians from all social strata, from the simplest person to kings and bishops. Jewish women were active as pawnbrokers in this market.

The second part (chapters 4-5) examines the way in which the holding of these objects led to a transformation of aesthetic values in Jewish communities. It was reflected in Jewish home decorations, garments, and manuscripts. One of the most exciting findings discussed in this part was the discovery of frescoes in the house of one of the most prominent Jewish sages of the time, Rabbi Moshe Ben Menachem, from the fourteenth century. Also known as Moses of Zurich, he authored a book of halakhic glosses on earlier works, called Semak Zurich. Rabbi Moshe's house was decorated with coats of arms of Christian nobles of his area and human figures dancing and riding on horses.

In the third part (chapters 6-7), Shatzmiller examines the highest point of cultural exchange, artistic collaboration between Jews and Christians in creating and decorating books, ritual objects, and even the interior of churches (p. 140). It seems that for medieval Christians and Jews in the period he studied, the quality of the artist was more important than his religion.

Shatzmiller succeeds in portraying the deep assimilation of a Jewish minority into Christian society. The picture that emerges in his study is of two communities involved in a lively and friendly interaction, based on mutual trust. Christians who deposited their pledges with Jews did so out of necessity, but on the whole they trusted the Jewish lenders. Christians deposited both everyday objects and objects of great value, such as 
crowns belonging to dukes and kings, gold and silver chalices, sacred books, and ornamented crosses. These objects were entrusted to Jews, to be returned as given.

It seems that collaboration, neighborliness, and mutual appreciation - mainly among professionals - succeeded in overcoming the differences between religions. Even the repeated warnings of church leaders against using ritual objects as pawns shows that the warnings were mostly ignored (p. 37). It is important to note that church leaders' protests were mainly against Jews, who feared that Jews would desecrate sacred objects. (For example, Jews were accused of feeding their children cookies dipped in wine that was held in chalices.)

Infrequently, the parties to a transaction went to court, though this was the exception that proves the rule of generally good relations (p. 159).

Although there were medieval scholars on both sides that opposed the holding of sacred objects, there were other scholars who found solutions to smooth out practical problems, often bending the rules of their religious communities. In Germany, Rabbi Eliezer ben Nathan (Ra'avan; ca. 1090-1170) claimed that it is not necessary to see the church as a place of worship for Christians, since Christians, he said, are coming to church primarily for pleasure rather than for worship: "When they visited the church they did so for enjoyment, not out of devotional commitment" (p. 31). His attitude enabled Jews to possess cleric's ritual objects. Shatzmiller uncovered such complexity within each community, highlighting similar gaps between ideology (dictated by some religious leaders) and everyday life.

His choice to focus on a site of cultural encounter - the marketplace - and not on the lasting implications of this encounter enabled him to offer a broad and deep portrait of this encounter. He contributes to a changing perspective of Jewish historiography on medieval Jewry. In daily life, it 
appears that Jews did not feel they lived fragile lives as a religious minority in a Christian society.

Although Shatzmiller claims that other scholars, among them Bezalel Narkiss and Colette Sirat, have dealt with some of the issues he discusses, his study succeeds in painting a rich, nuanced, original, and highly readable analysis of the interactions between the two communities. 